\title{
Marx's Theory of International Communication and Its New Development in China
}

\author{
Fei Wang \\ Research Center of Socialism with Chinese Characteristics \\ Dalian University of Technology \\ Dalian, China 116024
}

\begin{abstract}
Marx attaches great importance to the investigation of the social role of communication and points out that the essence of capitalist communication (mutual exchange) is "mutual plunder" and "slavery". In foreign exchanges, it is manifested in the exploitation of the people of backward countries by developed capitalist countries. And it was followed by the protection of trade in each other's interactions; the third was the war waged by various countries for the protection of trade; finally, in the international exchanges, the rule of the colonial people in particularly developed capitalist countries was not only plundered but also achieved enslavement. The idea of "cooperation and win-win" proposed by the "The Belt and Road" initiative and the principle of "Closer, sincere, favorable, inclusive, sharing business building sharing" are the development of opposing the idea of "violent interaction"; "Interaction, Mutual Learning, and Mutual Recognition" is The overcoming of "communicating alienation"; the goal of "human destiny community" is to fulfill the prelude of human "liberation". The "The Belt and Road" initiative is a practical innovation of Marx's communication theory. The concept of "human destiny community" is the theoretical development of Marx's communication theory. They all embody the theoretical qualities of Marxism that advance with the times.
\end{abstract}

Keywords-Marx; communication; "The Belt and Road" initiative; human destiny community

\section{INTRODUCTION}

"Communication" is one of the core concepts in Marx's thought. In his view, society "is the product of people's interactions." "All history conflicts are rooted in the contradiction between productive forces and forms of communication." ${ }^{[1](567-568)}$. Therefore, he personally attached great importance to the investigation of interaction and its role in social development. However, because of the requirements of the times and the historical conditions, he did not have enough time and energy to systematically study the issue of communication, nor could he provide specific suggestions to socialist country that was later "surrounded" by capitalism. However, his important expositions on social and historical significance of communication and critiques of capitalist exchanges are still of profound enlightenment significance so far, providing a philosophical basis and theoretic cornerstone for the Chinese government's proposal of the "The Belt and Road" Initiative and the concept of "human destiny community" in the new era.

\section{MARX'S CRITIQUE OF CAPITALIST FOREIGN CONTACTS}

Marx's critique of capitalist contacts was scattered in "Economic and Philosophical Manuscripts of 1844", "German Ideology" "Chinese Revolution and European Revolution", "Britain's Domination in India", "The Future of Britannia in Indian Rule," and a large number of books and articles. In these works, Marx pointed out that the capitalist communication is characterized by exchange and trade, and that exchange and trade are in fact alienated forms of social communication. Because in Marx's view, the real human interaction activities should be rich and varied, it is a "life expression" of human beings, a requirement of human sociality, and an obvious manifestation of human sociality. "The activities of direct interaction with others, etc., have become an organ of my life and a way of occupying human life." ${ }^{[2](86)}$ However, under capitalist conditions, exchanges have only manifested itself in the form of alienation of exchange and trade. "We have seen that national economists have defined the forms of alienation of social interactions as essential and original, and in conformity with human missions." ${ }^{2[2](172)}$ This alienation is what Marx said, the essence of mutual exchange is mutual plunder and enslavement.

Capitalist economists advocate that the exchange under capitalism is to fully respect the free will of each market entity and to implement equal exchanges. However, this kind of equivalent exchange is only a superficial complement, and its essence is "mutual plunder". Because each individual in the exchange is self-interested, and the value of certain commodities in the market is certain, for their own profit, they must raise the prices of their products, otherwise they would be unprofitable, and the exchange essentially would be a kind of "predatory." In the contest between the two sides, whoever is smarter, more powerful, more perseverant, or who is more devious, whoever gains an advantage will get the pricing power. In spite of the accidental nature of being looted in a specific incident, but as a whole, mutual plundering is an inevitable trend and result.

Under capitalism, the purpose of a person's exchange is to obtain the other's product. Then, in this person's view, the other person is only the means and tools for producing the goods they need; in turn, the same is true of "this person" in the other person's view, and it also appears to be a means and tool for producing his desired items. In fact, everyone in the 
exchange of capitalism has turned himself into a means and tool in the mind of the other party, and has become the production means and tool for the goods that the other person needs. Therefore, first of all, people are mutually used as tools and tools to enslave each other; secondly, all people become the means and tools for the production of all goods, that is, they are enslaved by all objects. "If we are enslaved by things, the state of slavery in the early stages of development actually shows a relationship of domination and enslavement, then this is only a rough and forthright expression of our essential relationship." ${ }^{22](183)}$

Language is the most convenient tool and medium for interaction between interacting subjects. It is a product of the formation of history in the process of human beings. However, "human language", the most primitive and basic human behavior, has failed under capitalism. Marx criticized, "We do not understand human language, and it is no longer valid." ${ }^{[2](183)}$ Under the conditions of capitalism, the only tool or intermediary for human interaction is the goods. "In short, the exchange between the two sides must be mediated by the goods produced and possessed by each party... In my mind, the only thing that can provide value, worth, and effectiveness to my needs is your goods, that is, the equivalent of my goods." 2$](183)$ Because in the exchanges under capitalist conditions, the relationship between human beings is bound to be the relationship between the private owner and the private owner, it must be the relationship between a special occupant and another special occupant. Possession of goods becomes the only valid evidence to verify one's personality, characteristics, power, and ability. "The only language we can use when we talk to each other is the object we have to be related to each other."[2](182) In the human interaction, the language becomes despicable and rejected by people shameful, that people who have personality, characteristics, power, and ability are dismissive of using such tools of communication. "It was seen and understood by one part as a request, a grief, and thus was seen as humiliating, so when it was used there was a feeling of shame and stigmatization; it was interpreted by the other part as shameless or deranged, and thus was refuted ". ${ }^{[2](183)}$

What is ineffective with language is the nature of man. In the product exchange relationship under private ownership, the only thing that is focused on is the product. The only thing that is valuable is the product. As for the product producer, the person, for both sides of the exchange, has no value or significance." For us, our mutual value is the value of the items we have for each other. Therefore, it seems to us that oneself is something of no value to another person." ${ }^{[2](183)}$

Marx's critique has a distinct embodiment in capitalist foreign relations. The first is the exploitation of the people of backward countries by the developed capitalist countries. Marx's description and criticism of the exchange between Britain and China at that time very objectively explained this issue." Before 1830, Chinese people were often surplus in foreign trade, and silver continued to be exported to China from India, the United Kingdom, and the United States. But from 1833, especially since 1840 , the silver output from China to India almost brings a danger of depletion of the silver source of the heavenly empire." ${ }^{[3](114)}$ The British trade has changed from a deficit to a huge surplus. This is ostensibly accomplished in the market of equivalent exchanges, but in fact it is a "plunder" under the compulsion of British artillery. This plundering of wealth not only overwhelmed the Chinese people, but also destroyed the spiritual support "patriarchal authority" on which the national machine of the great heavenly nation is based. "In addition to these direct economic consequences, offering or accepting bribes related to private opium corrupted the state bureaucrats in the provinces of southern China. The corruption of those bureaucrats who indulged in smuggling opium had gradually destroyed the "patriarchal authority" that the only spiritual connection between the parts of this gigantic state machine." [3](114)

This is followed by trade protection in various countries' interaction with each other. When capitalism was just on the stage of history, its performance was relatively primitive and forthright. Trade protection is mainly achieved through two means: one is the export of gold and silver is prohibited; the other is privilege. "In the era we are talking about, the relations established by countries in their interactions have two different forms. Initially, due to the small amount of circulating gold and silver, these metals were exported; on the other hand, industry, that are indispensable for providing job opportunities to the growing urban population, most of which are imported from abroad, does not work without privilege. Of course, such privilege can be used not only to counter domestic competition but also mainly to dealing with foreign competition." ${ }^{[1](563)}$ The ban on the export of gold and silver had continued for a long period of time, until the American silver and gold market emerged in the European market. Applying differential tariffs in overseas markets, that was most evident in Britain, the oldest capitalist country at that time. "The processing of domestically produced raw materials (British wool and linen, French silk) was encouraged, domestic raw materials (British wool) were prohibited from exporting, and [processing] of imported raw materials wad still discriminated against or suppressed (e.g. cotton in the UK)."[1](564)

Once again, all countries have launched wars to protect trade, that is, violence. In the second period of capitalist development, that is, from the middle of the 17th century, the ban on the export of gold and silver was abolished, and the old tariff policy was replaced by new tariff measures. The two traditional means of trade protection have not been adapted to the expanding needs of countries to interact with each other. Although competition among nations is constrained and regulated by tariff rates, bans, and various treaties as much as possible, this cannot fundamentally resolve conflicts and contradictions between all parties involved in the exchange. The capitalist nature of chasing profits makes the contradictions of all parties involved in the exchange irreconcilable, and the accumulation of contradictions and conflicts to a certain extent will inevitably lead to war. "Competition among nations is eliminated as much as possible through tariff rates, injunctions, and various treaties, but in the final, the struggle for competition is still carried out and lifted by war (especially naval warfare)." ${ }^{[1](563)}$ Three wars of the Anglo-Dutch War and the English-French war in 
the 17th and 18th centuries are the best illustrations of Marx's argument. Three wars of the Anglo-Dutch War and the Anglo-French War were all started with the struggle for sea power. Since the control of sea power controlled the ocean, the control of the sea controlled world trade.

Finally, in the international exchanges, the rule of the colonial people in particularly advanced capitalist countries was not only plundered but also achieved enslavement. Marx made a very objective assessment of British rule over India at the time. He quoted Stanford Raffers, the Governor of Java of the United Kingdom, describing what the Dutch East India Company had said to describe India under British rule at the time: "It's not as good for its subjects as the former West Indian planters for those slaves worked on the planting farms...it drove all the existing autocracy machines to crush its subjects, forcing them to give up the last thing and to pay the last bit of labor." [3](139) The enslavement of the colonial peoples by the advanced capitalist countries was cruel and terrible. Their brutality not only destroyed the local economy, but also destroyed the 1,000-year-old civilization. "British then destroyed the entire structure of Indian society, and there has been no sign of re-construction so far. The Indians lost their old world and did not acquire a new world. This has caused their current disaster to have a special kind of tragic keynote, and has broken off the contact between Hindustan ruled under Britain's rule with all its ancient traditions and has its entire history." ${ }^{[3](139)}$

\section{THE "BELT AND ROAD" InITIATIVE PRACTICE INNOVATION OF MARX'S COMMUNICATION THEORY}

\section{A. The Idea of "Cooperation and Win-Win" and the Principle of "Closer, Sincere, Favorable, Inclusive, Sharing Business Building Sharing" Developing in Opposing the Idea of "Violent Interaction"}

The idea of "cooperation and win-win" and the principle of "Closer, sincere, favorable, inclusive, sharing business building sharing" proposed by the Chinese "The Belt and Road" is a subversion of the concept of "losing one's selfish interests" of international contacts since the birth of capitalism. It is the subversion of the "carrot" and "stick" policies of the United States since World War II. It is also the creative development of Marx's ideas against violent communication in the new world situation. The international exchange since the birth of capitalism was the exchange of capital and the inevitable result of the natural development of the pursuit of profit by capital. Maximizing profit is the universal rule of the world market so far. In order to maximize profits, the competition of the main body of the market under the rules of the game that harms people and selfinterests is considered to be the dominant state of the relations between the subjects."The Belt and Road" initiative puts forward the concept of "cooperation and win-win". It is precisely this state of affairs. The Chinese government has adopted high-level leadership to promote and improve policies and measures, holding international summits, forums, seminars and expos in order to enhance understanding to consolidate consensus, to deepen cooperation, and to create a healthy development market environment for all countries participating in the orderly competition and benign competition of the main parties through common development and cooperation.

\section{B. "Overcoming Communication, Mutual Learning and Mutual Understanding" Overcome "Interaction Alienation"}

The international economic rules under the leadership of capitalism are, in essence, unilaterally beneficial development ideas. As long as it is unilateral income, the development of ideas dominates, the exchange of goods or material communication is essentially the decisive factor of its communication, is the highest baton of all its exchange activities. China's "The Belt and Road" is to change this kind of unilaterally beneficial development ideas and seek bilateral ideas of mutual benefit and common development instead. Only under the guidance of such bilateral thinking, the development of communication can make the enrichment of its connotation realistic. "The Chinese government has used the cultural symbol of the "Silk Road" to convey an idea to the world that is "peace, cooperation, development, and mutual benefit" [5]. "The Belt and Road" initiative, borrowing from the ancient Silk Road, means adhering to the spirit of the ancient Silk Road and making it an economic road not only for business exchanges and trade exchanges between countries along the way, but also a civilization road promoting the progress of human society for countries along the way in the exchange of goods and Mutual Learning and Mutual Understanding.

At the opening ceremony of the sixth ministerial meeting of the China-Arab Cooperation Forum, President Xi Jinping emphasized that "promoting the spirit of thinking means promoting civilization and mutual understanding. Human civilization has no distinction between merits and demerits, and it becomes rich and colorful because of equal exchanges. As the saying goes, "Five colors give brilliance to each other, and they complement each other; the octave is an ensemble. It is final and peaceful." "5] "Civilization and mutual understanding" is not only the basic principle put forward from the practical requirements of national communication, but also the strategic idea put forward at the height of human civilization and world peace development. The presentation of this strategic vision by Chairman Xi Jinping in his speech at the UNESCO Headquarters vividly portrayed the goals of the Chinese Communist Party and the manifestations of social ideals in the world today, namely, make due contributions in the progress of human civilization and the peaceful development of the world.

\section{THE CONCEPT OF "HuMAN DESTINY COMMUNITY" DEVELOPING IN MARX'S COMMUNICATION THEORY}

Marx emphasized that personal liberation and personal spiritual enrichment are also determined by interaction. He said, "As for the individual's spiritual richness in reality depends entirely on the richness of his real relationship, according to the above statement, this is already very clear." 3 ] That is to say, the results and products of social activities determine the richness of the social relationship or the actual 
relationship between people, and the richness of the human relationship determines the spiritual richness of the individual.

The concept of "human destiny community" is the negation of the interest concept of "exclusive zero-sum relationship". The establishment of a common interest view is conducive to peaceful coexistence and win-win cooperation in international relations. The traditional interest relationship of the international community has been described as an exclusive zero-sum relationship. This relationship is the result of long-term competition among various forces. It in turn reinforces people's sense of competition. It is so cyclical and continuously strengthened. It often leads to the deterioration of international relations, even hostility and war. The idea of the fate community concept is to guide people who have gone astray, jump out of this vicious circle, and move toward a virtuous circle, and enhance the long-term peace, stability, and prosperity of international relations.

The concept of "human destiny community" is the responsibility for global issues. The establishment of a common responsibility concept is conducive to the discussion and resolution of global issues. Global issues such as population, environment, food, energy, disease, and terrorism pose a severe challenge to the international order and human survival. Only when the international community reaches consensus on these issues and takes active action, the "public pasture" tragedies can be avoided. As early as 1996, China formally designated sustainable development as one of the country's basic development strategies and has achieved tremendous success. The Chinese government is willing to continue to work with the people of the world on itself and the world and create a better ecological and social environment for the world's economic and social development.

The concept of "human destiny community" is the sublimation of the concept of global governance. The establishment of a common outlook on fate is conducive to the establishment of a new international order. The establishment of the Global Governance Committee hinted at the failure, incompetence and reaction of the traditional international old order. The new world order is gradually emerging in the competition of various forces. To establish a new order that is in the interest of most of the world's people and truly meets the interests of most countries in the world, we must establish a scientific concept of global governance and establish a common outlook on destiny.

The concept of "human destiny community" is conducive to promoting the harmonious development of the world and is conducive to the establishment of rich communicative relationships among people of different countries, nationalities, cultures, and beliefs, and to increase the richness of the actual relationships of individual life, creating a prerequisite for personal "liberation".

\section{CONCLUSION}

"The Belt and Road" initiative and the "human destiny community" idea are pointed by the Party Central Committee, with Comrade Xi Jinping as the general secretary, proceeding from reality and seeking truth from facts, actively responding to the profound changes in the global situation, and coordinating the two major domestic and international initiatives and concepts. "The Belt and Road" initiative has given the ancient times of the Silk Road a spirit of "peace and cooperation, openness and inclusiveness, mutual learning and mutual benefit". It has also innovative cooperation model in helping the Chinese and participating countries to further expand exchanges (external contacts) and achieving mutual benefit, and provided new opportunities for China to comprehensively deepen reforms (internal contacts). It also provided an important way for optimizing the global governance structure and forming a new world development order, thereby injecting new impetus into the harmonious development of the world.

The "human destiny community" answers the question of what kind of world China is pursuing to build, demonstrates China's history and responds to the world's expectations of China. The concept of "human destiny community" is the negation of the interest concept of "exclusive zero-sum relationship", is the responsibility for global issues, and is a sublimation of the global governance concept. It is conducive to promoting the harmonious development of the world, and for the people of different countries, nationalities, cultures, and beliefs, it is conducive to establish rich communicative relationships, to increase the richness of the individual's reallife relationships, and to create the preconditions for the individual's "liberation." The concept of "human destiny community" has extremely rich connotations and important world historical significance. It is the innovation and development of Marxist communication theory under the new conditions of human social history.

\section{REFERENCES}

[1] Volume 1 of the "Marx and Engels Collection", Beijing: People's Publishing House, 2009 edition.

[2] Marx: "Manuscript of Economics and Philosophy in 1844", Beijing: People's Publishing House, 2000 edition.

[3] Complete Works of Marx and Engels, Volume 12, Beijing: People's Publishing House, 1998 edition.

[4] Xi Jinping talks about governance, Beijing: Foreign Language Press, 2014. 